\title{
Consumer Loyalty Interfaces with Website Quality
}

\begin{abstract}
The paper analyses the possibilities of how to increase customer loyalty by using different website quality tools. The research problem is defined as a question: How to link website quality and consumer loyalty? Data was gathered using scientific literature analysis and analysing other existing research. The results were provided based on the experts' interviews.
\end{abstract}

Keywords: website quality, customer loyalty, quality content.

Šiuo straipsniu siekiama išsiaiškinti, kaip padidinti vartotojų lojalumą naudojantis skirtingais internetinių svetainių kokybę gerinančiais elementais. Tyrime keliamas probleminis klausimas: kaip susieti internetinès svetainès kokybę ir vartotojų lojalumą? Duomenys gauti atlikus mokslinès literatūros analizę ir kokybinị giluminio interviu tyrimą. Rezultatai buvo gauti išanalizavus transkribuotus giluminių interviu tekstus.

Raktiniai žodžiai: internetinès svetainès kokybė, vartotojų lojalumas, kokybiškas turinys.

\section{Introduction}

Loyalty these days is one of the most important themes. Every shop wants to have a big group of loyal consumers. A. Budianto (2019) said that "the relationship effort is an active business of retail in contributing to customer expectations to realize customer retention through the delivery of core products and services that create sustainable relationships or create customer loyalty". This concept can be added to physical or website shop.

The object of analysis: interfaces between consumer loyalty and website quality.

The pursued goal analyses the ways how to engage more customer's loyalty by using different website quality tools.
The research problem is defined as a question: How to link website quality and consumer loyalty?

The loyalty idea in marketing is not a new one. Back in the 1700 s, loyalty actions were seen in physical craft shops (Duindam, 2019). Later on, around 1900's Frequent Fliers loyalty program was born. At the same time, some other loyalty programs were used as well. The most common communication form was WOM (word of mouth), so a good loyalty program could attract lots of good feedbacks from consumers (McEachern, 2018).

In today's market, we can find similar examples. We try to give customer reason to come back (for discounts, good quality and etc.), at the same time we try to build 
good relationships with consumer and get good feedback.

Nowadays, there is very big competition between retail stores, websites or even personal space in some kind of website (Budianto, 2019). Online stores are the best examples of that. According to multiple sources, there are more than 650,000 online stores who generate annual sales of more than $\$ 1,000$ per month. No matter that there are more than 12 million online stores in the World Wide Web. Even more impressive is the amount of sales on websites. Only in 2017, retail e-commerce websites are able to make sales amounted around 2.07 trillion Euros and this number will rise every year according to Statista (2018). These numbers show that the number of website consumers are rising as well. According to A. Budianto (2019), all companies going to face more demanding consumers, but the biggest problem is how to keep them all in your website store. That's why online loyalty programs and researches are so important for today's market.

\section{Online loyalty programs}

First of all, to understand different types of loyalty programs we have to know loyalty types. We can find lots of different types in case of consumer loyalty: behavioral, attitudinal loyalty, monogamous, polygamous loyalty (Aggarwal and Shi, 2018). We even different consumers by the type of loyalty program: never, light, heavy and extreme program users (Magatef and Tomalieh, 2015).

Behavioral loyalty can be defined as a form of loyalty when a customer continues to buy and use selected product of service despite other options. Also, it accumulates the business environment because consumers like to promote products that they are using (Warleta et al., 2016). B. Garcia Gomez et al. (2006) research results show persons who were in some kind of loyalty program before, will have positive behavioral to the new loyalty program.

According to G. M. Warleta et al. (2016), attitudinal loyalty is based on psychological factors: 1) Consumer wants to be part of the company; 2) Consumer willing to accept product, service or brand with higher price; 3 ) Consumer will resist competitors' offers and spread good word about company (Warleta et al., 2016). F. Liu et al. (2012) made an experiment and finds that users with attitudinal loyalty are more willingly buy product, service or brand which is more expensive. Other results show that imagery congruity has significant effects product or service exception and attitude. Monogamous loyalty meaning that consumers spend most of their time and money at one location and only that location.

Polygamous loyalty - when a customer shops at a few locations that offer similar products, but only those few locations (Aggarwal and Shi, 2018).

Types of customer loyalty program users:

Never. These users are not looking for some kind of reward form loyalty programs. They have not time or interest to gather points/coins or other loyalty program currency. These users are more often looking for quality merchandise then extra gifts or other benefits. Also of these type of users are not interested in website design, content or system services. Loyalty programs' benefits have no impact on customers' decision making. 
Light. These users are willing to get information about loyalty program benefits. This kind of individual is not interesting in collecting points but willing to buy some product or service is they get extra value immediately. This segment has a large number of consumers with different characteristics. These people are willing to get loyalty cards but there is an opportunity that they going to use that cant one or two times.

Heavy. These users are willing to participate in a loyalty program, they will be active and motivated to get points or other loyalty program currency. These types of users may also buy more products or services during loyalty program time. Also, heavy loyalty users are looking for long term benefits and recognitions among other users. They also have a good attitude about the company and/or brand.

Extreme. These users are not even participants of the loyalty program but also developers. They are willing to send feedback about the loyalty program. They are also motivated and active participants. These consumers are willing to invite more people to loyalty program action if they get some benefits from that. They also track their points and benefits that they get and spread a positive attitude about the company and loyalty program (Magatef and Tomalieh, 2015; PR Loyalty Solutions, 2011).

Turning customers into website or shop loyalists is very hard work. According to S. G. Magatef and E. F. Tomalieh (2015), "only $12 \%-15 \%$ of customers are loyal to a single retailer. But this number of loyal customers generate between $55 \%-70 \%$ of company sales". Statista review (2018) revealed that current online shops is a common activity by lots of people worldwide.
Online in 2016 around 19 percent of all sales in China were made by online shops, Japan around 7 percent. Worldwide this number increasing every year.

To increase this number most of the websites are using loyalty programs. Online loyalty become an effective tool to invite and keep customers. Loyalty programs help to increase revenues and increase existing loyalty. Nielsen's (2013) study showed that more than 84 percent of consumers will stay in the website shop if they get real benefits from the loyalty program. Here are a few the most popular loyalty programs:

The Points Program - very simple "spend more earn more points", also you can get points for reviews and feedbacks. This program is the most common one in all rounds of websites. Points that you get for buying you can trade to the next discount or some extra gifts or merchandise. It is very popular in short-term merchandise shops (Peiguss, 2012).

The Paid Program - gives you VIP benefits for invitations into the website. Most of the time you have to pay for the program some small amount of money. Benefits could be discounts for future purchases, extra merchandise or special offer. The most common example can be a "Patron system", where customers paid some amount of money to get extra content or other goods/discounts (Peiguss, 2012).

The Charity Program does not include discounts. These (Charity) programs allow you as a customer to donate some money to charity foundations. Most of the time websites add extra money to charity foundations from your purchases. This kind of loyalty program also shows company social responsibility. 
The Tier Program is based on different stages or levels of loyalty. This type of program enables one to increase your tier and get bigger benefits like discounts, free staff or special offers (Kopalle et al., 2012). This type of loyalty program most often is used in hotels, airlines, ticket websites and big online shops.

The Partner Program - a system based on partners' goods and discounts. With this type of loyalty program, the customer gets the opportunity to get an extra discount or/and gift from your partners. This loyalty program is most popular in corporations like NIKE, Adidas, Puma and etc. This type of loyalty program includes different bases like websites, apps, real stores, and events.

The Community Program - it is a mix of loyalty programs, which allows customers to get extra benefits when they invite more customers to the website or store. Most of the time Tier/Points/VIP systems are mixed in one system.

Frequent Buyer Program - gives your discounts for the amount of purchases you made, also includes special offers and extra information (Magatef and Tomalieh, 2015). This program is mostly used to get immediately fast sells and increase loyalty over a period of time.

There are also lots of other loyalty programs like extra value, benefits by buying more, cards and certificates are also included. But these programs are rare in online shops. Most loyalty programs are giving good benefits for both (customers and business) sides. For business, retain your customers more productively, gives good feedback. Your business will more desirable to consumers and their friends. For customers business to provide extra value for loyal customers, existing cus- tomers have the opportunity to save some extra money for the next purchases. So overall customer loyalty programs help to get more loyal customer by giving them extra benefits and allowing them to feel special. But there is one more major factor that can decide customer loyalty in online store, its overall website quality.

\section{Website quality factors}

Your website is the face of your organization, and many people expect to find everything they want and need on your company website. We can think that if you add attractive design, good colors, and lots of content, users will more likely to visit and stay on your website. But is it? There are two sides of website quality. It calls "User Testing vs. Quality Assurance”. User testing is orientated to user experiences at browsing time, how he understands website quality while looking for his own goal. There is a huge argument in science which is better one. Most of the time the answer is very unclear and the $3^{\text {rd }}$ mix group shows up (Hsu et al., 2018). Quality Assurance group are using factors like overall quality, content quality, service quality, system quality. While User testing group using factors like accessibility, perception, quality understanding, loyalty, and etc. $3^{\text {rd }}$ group are willing to mix everything up in case of the aim. Here are some tips and results from all three sides.

Quality and unique content. Quality content could be text information, videos, some kind of sound or other digital content. All content is added purposeful with inattention to satisfy consumer needs (Bulygo, 2019). 
SearchMetrics (2018) mentions that Google search algorithm can recognize high-quality content and give website higher ranking. In long run website which have good quality content will gather group loyal users. But not only content is the main concern, system and service quality is also very important (Shiller, Waldfogel, Ryan, 2018).

Content length. According to M. Hogue et al., (2018) website with more than 1000 words, most of the time have the number one ranking in Google search. Content length depends on multiple factors like website purpose and company size. So most of the websites focus on longer more detail content. Best way to get up your website or blog is SEO (Search engine optimization). From SEO perspective best content length is around 2500 words. The number of words depends on website purpose, size, and consumers (QuickSprou, 2019).

Readability. This is one of the most important website quality aspects. If content will be hard to read and understand and if the customer will have a hard time to reach content, then you will customer for sure. There is also a recommendation to use short sentences which is easy to read and understand. Also, remover all not necessary marks or other content which is not related to customer goals (QuickSprou, 2019). You have to ensure that articles would be easily understood and share between other platforms (Sheats, Royal, Kedrowicz, 2019).

Images and video. Z. Bulygo (2019) argues that video and pictures are more attractive to customers than regular typed information. Also, unique names and named images can help a website get with better SEO page ranking. Top websites usually have around 7 named images. The customer's first attention is going to image then to his eyes are moving other information. Pictures and video quality is also very important, they have to representative web page or brand (QuickSprou, 2019).

Social media. QuickSprou (2019) stated that top websites are including social media (Facebook, LinkedIn, Google+) buttons in register or connection part. According to E. Raguseo (2018) and M. H. M. Sharif et al., (2018), nowadays social media users, especially influencers, become more equal to companies. Users can send a message or demonstrate a product to a big audience, which can make an impact on company sales. Now influencers can build their own brands or public opinions about something. B. A. Nedra et al., (2019) highlighted the main benefits from social media like sharing videos or images, writing feedbacks, using hashtags, engaging with other users, engaging with other trademarks or brands.

Overall quality. Overall website quality most of the time have three different quality categories. Information or content quality - all videos, text information, sound or images. System quality which related with easy to use and understand. Service quality - which is related to website services like live chats, interactivity or security. Nowadays it becomes very important to identify customer need and ensure that overall website quality match customer expectations (Tandon et al., 2017). Overall quality is the interface between website quality and consumer perception. H. H. Chang et al. (2009) tried to measure the relationships between perception and customer satisfaction on the website. Results show that there is a 
significant effect of e-service quality on customer trust and satisfaction. All these factors (trust, perception, satisfaction) are very important in building customer loyalty.

\section{Research method}

The aim of this research paper is to theoretically test the ways how to engage more customer's loyalty by using different website tools or factors. We select an in-depth interview. This type of research does not intend to offer final and conclusive solutions to existing problems but gives a way to understand potential customer needs and priorities. Goals are to understand human behavior, expectations and emotions (Tong et al., 2012). This method has been chosen, because of the necessity to understand consumer behavior, experience and expectation in different websites. Most of the time in-depth interviews we are talking face to face but in this case, there was no chance to get real face to face interview because of the distance. We had to use "Skype" and "Messenger" to connect with our respondents. In this particular study, 4 respondents were selected.

All respondents have different experiences in website quality and loyalty de- velopment; also, they all have experience with consumers in digital space. These indepth interviews follow the general plan:

1) Identify customer quality and loyalty understanding;

2) Identify consumer priorities in website;

3) Find out interfaces between website quality and consumer loyalty.

All interviews were digitally recorded and transcribed. During the interviews, the respondents answered the proposed 7 questions. There was no time limit or any other restrictions. The analysis of answers is presented by means of comparison analyzing all the answers within the first question, one by one. Pictures and tables were created by the article author.

\section{Results}

The first question was related to customer quality understanding. All respondents concluded that the visual part (design, information layout) of the website is very important. Also, they mentioned several different factors that can affect quality understanding:

1) Easy to use;

2) Information sources;

3) Customers feedback;

4) Popularity (number of orders).

Table 1. Selected respondents for interview

\begin{tabular}{|c|c|}
\hline Respondent info & Involvement into Web/loyalty analysis \\
\hline $\begin{array}{c}\text { Dr. Li Yisong, Assistant Professor, College of Manage- } \\
\text { ment, Beijing Sport University }\end{array}$ & $\begin{array}{c}\text { Human resources analytics, lector in website } \\
\text { management. }\end{array}$ \\
\hline $\begin{array}{c}\text { Kathy Schrock, online adjunct graduate-level professor } \\
\text { for Wilkes University }\end{array}$ & $\begin{array}{c}\text { Adobe specialist, a Google specialist, an Apple Teacher } \\
2016\end{array}$ \\
\hline $\begin{array}{c}\text { Karolina Grigaliauskaite, "Neo-Reklama” Expert of } \\
\text { Outdoors Advertisiment }\end{array}$ & $\begin{array}{c}\text { Master degree of marketing, digital marketing } \\
\text { specialist. }\end{array}$ \\
\hline $\begin{array}{c}\text { Raminta Tarnauskaite "2066 Digital Agency" social } \\
\text { media project manager }\end{array}$ & Digital marketing specialist, specialist in social \\
networks.
\end{tabular}


Without technical factors they all agree that content is very important, website content that is accessible should meet customer expectations. At the same time, you have to make the website easy to read and understand after that it becomes possible that customers who visit the website will stay longer and come back again.

The second question brings to customer loyalty. We ask which factor or factors affect customer loyalty? R. Tarnauskaite said that "How your product or a website plays in the media, both commercial and social (in case of functionality, design and easy to use), can influence long-term relationships between website which is selling product and customer who buying that product". K. Schrock agreed and add that "...the biggest factors for consumers to revisit a Web site is that they trust the creator to be an expert in the topic and that the information is updated or added to on a regular basis". Other factors were mentioned like website easy to use, usability, satisfaction, customer inclusion, elasticity and trust.

The third question was about the website evaluation. How should be website evaluated? What kind of criteria are included, etc. Respondents' answers were different; one of them said that it should be used official website evaluation models like " $5 w$ ", "SiteQual", and etc. Others said that they can use analytic statistics like "Google analytics" or users' feedback. Everyone agrees that most importantly is to satisfy consumer needs no matter how you do it. "However, keep in mind that just because a website is well presented does not mean that it contains accurate information" (L. Yisong).

The fourth question was given to find out which website elements are the most important for the consumer. The answers were quite similar, e. g., K. Schrock said: "I think that consumers first prefer a site that is easy to navigate so they can find what they need.... finally, the content that is provided on the site about the subject they are searching for". All respondents had the same thoughts about consumer priorities.

The fifth question reveals the experts' opinion about the elements that average consumer is evaluating in website all the time. Experts had different opinion about it. Some of them said that it depends on what type of Web site it is and suggest "Key Theory". Others mentioned universal categories like:

1) Security or safety;

2) Easy to use;

3) Trust.

Also, experts had some advice for regular users about everyday websites "Important part of the evaluation process is thinking critically - not believing everything you read or see, not settling for any kind of source of information, and always questioning."

The sixth question helped to find out about future website developer moves, how can they create and hold loyal customers. K. Grigaliauskaite mentioned that "They will get to know you by your browsing behavior and every visit will be a better experience". Without communication there was mention that "A lot of people today are using a mobile phone before they see a laptop or a PC", so that way more innovation ideas should be added in the mobile version. Also, experts mentioned: 1) Innovative functions (like $3 \mathrm{D}$ pictures); 2) Time-saving functions; 3) Face-to-face communication using webcams. 
Table 2. Summary of in-depth interviews

\begin{tabular}{|c|c|c|}
\hline $\begin{array}{c}\text { Consumer quality and loyalty } \\
\text { understanding }\end{array}$ & Website quality priorities & $\begin{array}{c}\text { Interfaces between website quality } \\
\text { and consumer loyalty }\end{array}$ \\
\hline $\begin{array}{l}\text { Quality } \\
\text { 1) Easy to use } \\
\text { 2) Information sources } \\
\text { 3) Customers feedback } \\
\text { 4) Popularity } \\
\text { Loyalty } \\
\text { 1) Trust } \\
\text { 2) Functionality } \\
\text { 3) Update information } \\
\text { 4) Inclusion }\end{array}$ & $\begin{array}{l}\text { Experts } \\
\text { 1) Easy to use } \\
\text { 2) Safety } \\
\text { 3) Trust } \\
\text { Consumers } \\
\text { 1) Navigation } \\
\text { 2) Content } \\
\text { 3) Search }\end{array}$ & $\begin{array}{l}\text { 1) Innovative function for } \\
\text { consumer inclusion } \\
\text { 2) Tame saving function } \\
\text { 3) Face to face communication } \\
\text { 4) Mobile friendly innovative ideas } \\
\text { 5) Website reliability and trust }\end{array}$ \\
\hline
\end{tabular}

Finally, the last question helped to find out interfaces between website quality and consumer loyalty. Two of the respondents answered that this type of interface should be related to consumer emotions, consumer feelings, and Neuromarketing ideas. The other two respondents answered that interfaces could be found in reliability, consumer inclusion and trust.

\section{Conclusions}

Loyal program purposes offer special promotions, products or discounts to customers in return getting their loyalty. The biggest strength of loyalty program, however, is how easy it is to understand. A successful and best customer loyalty program can boost profits and improve customer retention.
Customers are looking with highquality content like videos, images and text. Good quality could also be reach thought out good design, strong content, good system performance, effective and fast communication, social media image and overall quality. It's important to know that any single quality of loyalty factor could make an otherwise good website into a low-quality site.

Research results showed that consumers understand quality and loyalty throughout easy to use, content, good image, trust, functionality and inclusion factors. The experts' website priorities are safety, trust and easy to use. For consumers, priorities are content, navigation and search. Interfaces between website quality and consumer loyalty are innovative and time-saving functions, mobile friendly and close communication, trust, inclusion and reliability.

\section{References}

1. Aggarwal, P., Shi, M. (2018). Monogamous versus Polygamous Brand Relationships // Journal of the Association for Consumer Research. Vol. 3(2), pp. 188-201. doi: doi. org/10.1086/697078
2. Aladwani, A. M., Palvia, P. C. (2002). Developing and Validating an Instrument for Measuring User-Perceived Web Quality // Information \& management. Vol. 39(6), pp. 467-476. 
3. Budianto, A. (2019). Customer Loyalty: Quality of Service // Journal of Management Review. Vol. 3(1), pp. 299-305.

4. Bulygo, Z. (2019). The Elements of a High Quality Website (Infographic). Internet access: $<$ https://neilpatel.com/blog/elements-highquality-website/ $>$ [accessed July 1, 2019].

5. Chang, H. H., Wang, Y. H., Yang, W. H. (2009). The Impact of e-Service Quality, Customer Satisfaction and Loyalty on e-Marketing: Moderating Effect of Perceived Value // Total Quality Management and Business Excellence. Vol. 20(4), pp. 423-443. doi: doi. org/10.1080/14783360902781923

6. Duindam, J. (2019). Crossing Boundaries: Diplomacy and the Global Dimension, 17001850 // The International History Review, Vo. 41, Issue 5, pp. 1-8. doi: doi.org/10.1080/07075 332.2018 .1533488

7. García Gómez,B., Gutiérrez Arranz,A., Gutiérrez Cillán, J. (2006). The Role of Loyalty Programs in Behavioral and Affective Loyalty // Journal of Consumer Marketing. Vol. 23(7), pp. 387-396. doi: doi.org/10.1108/07363760610712920

8. Hoque, M., Alsadoon, A., Maag, A., Prasad, P. W. C., Elchouemi, A. (2018). Comprehensive Search Engine Optimization Model for Commercial Websites: Surgeon's Website in Sydney // JSW. 13(1), pp. 43-56. doi: doi. org/10.17706/jsw.13.1.43-56

9. Hsu, C. L., Chen, M. C., Kumar, V. (2018). How Social Shopping Retains Customers? Capturing the Essence of Website Quality and Relationship Quality // Total Quality Management \& Business Excellence. Vol. 29(1-2), pp. 161-184. doi: doi.org/10.1080/14783363.2016.1171706

10. Kendal Peiguss (2012). 7 Customer Loyalty Programs That Actually Add Value // Internet access: <http://blog.hubspot.com/blog/ tabid/6307/bid/31990/7-Customer-Loyalty> [accessed July 1, 2019].

11. Kopalle, P. K., Sun, Y., Neslin, S. A., Sun, B., Swaminathan, V. (2012). The Joint Sales Impact of Frequency Reward and Customer Tier Components of Loyalty Programs // Marketing Science. Vol. 31(2), pp. 216-235. doi: doi. org $/ 10.1287 / \mathrm{mksc} .1110 .0687$

12. Lee, G., Lin, H. (2005). Customer Perceptions of e-Service Quality in Online Shopping // International Journal of Retail \& Distribution Management. Vol. 33(2), pp. 161-176. doi: doi. org/10.1108/09590550510581485
13. Liu, F., Li, J., Mizerski, D., Soh, H. (2012). SelfCongruity, Brand Attitude, and Brand Loyalty: A Study on Luxury Brands // European Journal of Marketing. Vol. 46(7/8), pp. 922-937. doi: doi.org/10.1108/03090561211230098

14. Magatef, S. G., Tomalieh, E. F. (2015). The Impact of Customer Loyalty Programs on Customer Retention // International Journal of Business and Social Science. Vol. 6(8), pp. 7893. doi: doi.org/10.4324/9781315162829-2

15. Magatef, S. G., Tomalieh, E. F. (2015). The Impact of Customer Loyalty Programs on Customer Retention // International Journal of Business and Social Science. Vol. 6(8), pp. 78-93.

16. McEachern, A. (2018) A History of Loyalty Programs, and How They Have Changed. Internet access: <https://blog.smile.io/ahistory-of-loyalty-programs> [accessed July 2, 2019].

17. Nedra, B. A., Hadhri, W., Mezrani, M. (2019). Determinants of Customers' Intentions to Use Hedonic Networks: The Case of Instagram // Journal of Retailing and Consumer Services. Vol. 46, pp. 21-32. doi: doi.org/10.1016/j. jretconser.2018.09.001

18. Nielsen (2013). How Loyal are Your Customers? Internet access: <https://www.nielsen.com/us/ en/insights/report/2013/how-loyal-are-yourcustomers/> [accessed July 1, 2019].

19. PR Loyalty Solutions (2011). What is Customer Loyalty? Internet access: <http:// prloyaltymarketing.com/customer-loyalty/ what-is-customer-loyalty/> [accessed July 1, 2019].

20. QuickSprou (2019). The 22 Key Elements of a High Quality Website. Internet access: <https:// www.quicksprout.com/the-key-elements-of-ahigh-quality-website/> [accessed July 2, 2019].

21. Raguseo, E. (2018). Big Data Technologies: An Empirical Investigation on Their Adoption, Benefits and Risks for Companies // International Journal of Information Management. Vol. 38(1), pp. 187-195. doi: doi. org/10.1016/j.ijinfomgt.2017.07.008

22. Searchmetrics (2018). What is a Ranking Factor? Internet access: <https://www.searchmetrics. com/what-is-a-ranking-factor/> [accessed July 1, 2019].

23. Sharif, M. H. M., Troshani, I., Davidson, R. (2018). Determinants of Social Media Impact in Local Government. In Media Influence: Breakthroughs in Research and 
Practice, pp. 141-164. IGI Global. doi: doi. org/10.4018/978-1-5225-3929-2.ch008

24. Sheats, M. K., Royal, K., Kedrowicz, A. (2019). Using Readability Software to Enhance the Health Literacy of Equine Veterinary Clients: An analysis of 17 American Association of Equine Practitioners' Newsletter and Website Articles // Equine veterinary journal. Vol. 51(4), pp. 552-555. doi: doi.org/10.1111/evj.13042

25. Shiller, B., Waldfogel, J., Ryan, J. (2018). The Effect of Ad Blocking on Website Traffic and Quality // The RAND Journal of Economics. Vol. 49(1), pp. 43-63. doi: doi. org/10.1111/1756-2171.12218

26. Tandon, U., Kiran, R., Sah, A. N. (2017). Customer Satisfaction as Mediator between Website Service Quality and Repurchase Intention: An Emerging Economy Case //
Service Science. Vol. 9(2), pp. 106-120. doi: doi. org/10.1287/serv.2016.0159

27. Tong, A., Flemming, K., McInnes, Oliver, E. S., Craig, J. (2012). Enhancing Transparency in Reporting the Synthesis of Qualitative Research: ENTREQ // BMC Medical Research Methodology. Vol. 12, No. 1, pp. 181. doi:10.1186/1471-2288-12-181

28. Warleta, G. M., Ventisca, M. D. B., Gallo, M. P. (2016). Importance and Role of Retail Brands in a Non-Food Market: A Case Study of DIY Retailing in Spain. In Handbook of Research on Strategic Retailing of Private Label Products in a Recovering Economy, pp. 416-442. IGI Global. doi.org/10.4018/978-1-5225-0220-3.ch017

The paper submitted: July 10, 2019

Prepared for publication: December 20, 2019

\section{Antanas ŪSAS}

\section{VARTOTOJŲ LOJALUMO SĄSAJOS SU INTERNETINIỤ SVETAINIỤ KOKYBE}

\section{S a n t r a u k a}

Šiuo straipsniu siekiama padidinti vartotojų lojalumą naudojantis skirtingais internetinių svetainių kokybės elementais. Tyrimo probleminis klausimas: kaip susieti internetinès svetainès kokybę ir vartotojų lojalumą? Duomenys gauti atlikus mokslinès literatūros analizę ir kokybinị giluminio interviu tyrimą. Rezultatai buvo gauti išanalizavus transkribuotus giluminių interviu tekstus.

Pirmoje straipsnio dalyje kalbama apie lojalumo programų poreikị. Trumpai apžvelgiama lojalumo programų tobulejimo istorija. Pateikiama šių dienų internetinių svetainių ir parduotuvių statistika, pirkimo mastai ir prognozès. Apžvelgiami vartotojų tipai lojalumo aspektu, išskiriamas elgsenos ir požiūrio lojalumas. Išskiriami vartotojai pagal lojalumo programą: niekada nesinaudojantys, trumpai besinaudojantys, ilgai besinaudojantys lojalumo programų privalumais ir ekstremalai - influenceriai, kurie ne tik naudojasi lojalumo programų nauda, bet ir rekomenduoja ją kitiems. Apžvelgiamos internetinèje erdvejje taikomos šios lojalumo programos : taškų, mokejjimo, paramos, lygių, parnerių ir bendruomenès ir dažnų pirkèjų lojalumo programos.

Antrojoje dalyje kalbama apie internetinès svetainès kokybès veiksnius. Diskutuojama apie vartotojų ir internetinių svetainių kokybès supratimo skirtumus. Išskiriami pagrindiniai kokybės veiksniai, darantys ịtaką vartotojų kokybės suvokimui. Aptariami kokybiško ir unikalaus turinio, patikimumo, turinio ilgio, paveikslų ir vaizdinès medžiagos ir bendros kokybės veiksniai. Akcentuojama šių internetinès svetainès kokybès veiksnių svarba vartotojų lojalumui.

Trečiojoje dalyje aprašomas tyrimas, atliktas taikant interviu metodą. Apklausti 4 skirtingų mokslo ir verslo institucijų respondentai. Jie turèjo turèti patirties ir internetinių svetainių kokybès, ir vartotojų lojalumo klausimais. Tyrimo metu buvo siekiama sužinoti respondentų nuomonę apie vartotojo lojalumą ir kokybès supratimą, prioritetus internetineje svetaineje ir sąsajas tarp internetinès svetainès kokybès ir vartotojų lojalumo. Tyrimo rezultatai parodè, kad vartotojui kokybè siejasi su patogumu naudotis, informacijos užtikrintumu, internetinès svetainès populiarumu ir teigiamais atsiliepimais, o lojalumas - su pasitikejjimu, funkcionalumu ir issitraukimu. Prioritetai internetinių svetainių kontekste, ekspertų nuomone, yra saugumas, patogumas naudotis ir pasitikejimo formavimas. Inovatyvios ir laiką taupančios funkcijos, artimesnis bendravimas, internatinès svetainès patikimumas ir pasitikejjimas buvo įvardintos kaip sąsajos tarp vartotojų lojalumo ir internetinès svetainès kokybès. 